\title{
Determination of the optimal concentration of Minitube Equex paste for boar semen
cryopreservation based
} on sperm motility characteristics Junpen Suwimonteerabutr*, Morakot Nuntapaitoon and Padet Tummaruk



\begin{abstract}
Equex paste is a non-permeating cryoprotective agent (CPA) that improved post-thaw survival of spermatozoa during boar semen cryopreservation. However, Equex paste produced by Nova Chemical Sales Inc. (MA, USA) is not currently available. The aim of the present study was to determine the optimal concentration of Minitube Equex paste (Minitube, Tiefenbach, Germany) for boar semen cryopreservation in comparison with Nova Equex STM paste (control). Fifteen ejaculates from 12 mature boars were collected by the glove-hand method. Each ejaculate was aliquoted and cryopreserved in base freezing extender III as Tris-citrate egg yolk (TEY) extender plus $9.0 \%$ glycerol classified into four groups. Group I was the control and included only $1.5 \%$ Nova Equex STM paste. Groups II, III and IV were the experiment groups, and contained different concentrations of Minitube Equex paste
\end{abstract}

(Group II: 1.5\%; Group III: 1.7\%; and Group IV: $1.9 \%$ ) added to the freezing extender III. After freezing and thawing, sperm motility characteristics were evaluated by Sperm Class Analyzer ${ }^{\circledR}$ incubated at $37{ }^{\circ} \mathrm{C}$ for $0(10 \mathrm{~min})$, 1 and $2 \mathrm{~h}$ post-thawing. In Group IV after thawing at $0 \mathrm{~h}$, rapid velocity and the velocity curved line were significantly higher than in Groups II and III $(P<0.05)$ but did not differ from Group I. Moreover, after thawing at $1 \mathrm{~h}$, LIN (linearity) in Group IV was higher than in Group II $(P<0.05)$, but did not differ from the other groups. In conclusion, the most suitable concentration of Minitube Equex paste in the current protocol was $1.9 \%$ supplemented with 9.0\% glycerol in TEY-based freezing extender III, based on the conformity between data from manual guides and the observed sperm motility characteristics results.

Key words: boar semen; cryopreservation; extender; Equex paste; post-thawed motility

Junpen SUWIMONTEERABUTR*, (Corresponding author, e-mail: Suwipen@hotmail.com), Morakot NUNTAPAITOON, Padet TUMMARUK, DVM, MSc, PhD, Swine Reproduction Research Unit, Department of Obstetrics, Gynaecology and Reproduction, Faculty of Veterinary Science, Chulalongkorn University, Bangkok, Thailand 


\section{Introduction}

Cryopreservation is the most efficient method for long-term storage of boar semen (Yeste, 2016) as it can efficiently maintain and preserve the genetics of sires, including the control of transmission of certain pathogens. The cryopreservation protocol has many potentially damaging stresses: firstly, the change in temperature: secondly, the osmotic and toxic stresses caused by exposure to molar concentrations of cryoprotectants: and thirdly, the formation and dissolution of ice in the extracellular environment (Watson, 2000). Cryoprotective agents (CPAs) or cryoprotectants are used to reduce the stress arising from freezing and thawing. However, they may be toxic to sperm and therefore, optimisation of CPA concentration is crucial (Okazaki et al., 2009). There are two types of CPA: permeating and non-permeating. Permeating CPAs, such as glycerol, DMSO and ethylene glycol, have the ability to decrease the concentration of electrolytes and the extent of osmotic shrinkage at low temperatures. Nonpermeating CPAs, which do not pass through the plasma membrane, help to prevent ice formation, and stabilise proteins and cell membranes (Benson et al., 2012). The main ingredient of the surfactant Equex paste (or Orvus ES paste) is sodium dodecyl sulphate (SDS). It acts as a non-permeating CPA, as an emulsifier to the egg yolk particles of the extender, and promotes the cryoprotective effect by facilitating the interaction of egg yolk proteins with the sperm plasma membrane (Holt, 2000; Tomás et al., 2014). It has been used successfully for boar semen cryopreservation using an egg yolk base extender (Holt, 2000; RodriguezMartinez and Wallgren, 2010). Equex STM paste is a well-known supplement used in various animal species, such as cat, dog, goat, sheep, wild dog and elephant (Axnér et al., 2004; Ponglowhapan and Chatdarong, 2008; Alhaider and Watson 2009; Morton et al., 2010; Annakkul et al., 2011; Buranaamnuay et al., 2013; Panyaboriban et al., 2015; Van den Berghe et al., 2018) and pig (Buranaamnuay et al., 2009; Mercado et al., 2009; Chanapiwat et al., 2012; Pearodwong et al., 2019).

Sperm motility is one of the most important indicators for the evaluation of semen quality, (Kozdrowski et al., 2007; Karageorgiou et al., 2016). It manifests an active mechanism and membrane integrity and is positively correlated with fertilising capacity (Johnson et al., 2000; Vyt et al., 2004). During recent years, computer-aided sperm analysis (CASA) systems have been recommended by the revised WHO manual (World Health Organization, 2010) as a selective means to analyse semen samples, and have been widely used to assess sperm motility characteristics in boar semen (Vyt et al., 2004; Purdy et al., 2010; Tretipskul et al., 2010; Tremoen et al., 2018; Pearodwong et al., 2019).

The addition and removal of cryoprotectant in molar proportions is essential, though it induces osmotic stress to the plasma membranes of spermatozoa, depending on the relative permeability of the cryoprotectant (Gao et al., 1993). Equex paste produced by Nova Chemical Sales Inc. (MA, USA) is not currently available. We proposed the use of Minitube Equex paste (Minitube, Tiefenbach, Germany) as a replacement, though it is still not proven for use in boar semen cryopreservation. The purpose of this study was to determine the optimal concentration of Minitube Equex paste for boar semen cryopreservation compared with Nova Equex STM paste (as the control) based on sperm motility characteristics. 


\section{Materials and Methods \\ Animals and semen collection}

The experimental procedure was performed in accordance with the Ethical Principles and Guidelines for the Use of Animals, National Research Council of Thailand, and approved by Chulalongkorn University Animal Care and Use Committee (IACUC; protocol number 1931086).

Fifteen ejaculates from 12 mature boars (six Duroc, four Yorkshire and two Landrace) aged between 1 and 3 years were collected using the glove-hand method at a boar stud farm in western Thailand, and at the Large Animal Hospital, Faculty of Veterinary Science, Chulalongkorn University, from January to March 2020. The boars showed normal fertility and were routinely used as semen donors for artificial insemination on the pig farm. Ejaculates of boar semen with $\geq 70 \%$ subjective motility and $\geq 90 \%$ morphologically normal were included in the experiment. Semen was cryopreserved according to Pearodwong et al. (2019) with some modifications.

All basic chemicals were purchased from BDH, Poole, UK. The semen was diluted $(1: 1-2 \mathrm{v} / \mathrm{v})$ in a commercial boar semen extender (Duragen ${ }^{\circledR}$, Megapor, Zaragoza, Spain; Extender I) at $37{ }^{\circ} \mathrm{C}$ within $10 \mathrm{~min}$ of collection and transported to the laboratory in an insulated foam cooler kept at ambient temperature (15-18 ${ }^{\circ} \mathrm{C}$; Purdy, 2008). Semen samples were transported within 4 $\mathrm{h}$ of collection to the Faculty of Veterinary Science, Chulalongkorn University, Bangkok, Thailand. The diluted semen was cooled to $16{ }^{\circ} \mathrm{C}$ in a controlledtemperature refrigerator (LIEBHERR, Bulle, Switzerland) and equilibrated for $2 \mathrm{~h}$. After that, semen was centrifuged at $16^{\circ} \mathrm{C}$ and $800 \mathrm{~g}$ for $10 \mathrm{~min}$, and the pellet of sperm was diluted in Tris-citrate egg yolk (TEY) extender (111 mM Tris, $31.4 \mathrm{mM}$ citric acid, $185 \mathrm{mM}$ glucose, 20,000 IU penicillin and $100 \mathrm{mg} / \mathrm{ml}$ streptomycin, $\mathrm{pH} 7.2$ and $312.0 \pm 6.0 \mathrm{mOsmol} / \mathrm{kg}$; Mercado et al., 2009) plus 20\% egg yolk (Extender II) to a concentration of 1.5 $\times 10^{9}$ cells per $\mathrm{mL}$. The semen was then cooled to $4{ }^{\circ} \mathrm{C}$ for $2 \mathrm{~h}$.

To determine the optimal concentration of Minitube Equex paste, Extender III was divided into four groups (i.e., Groups I, II, III and IV). Two parts of extended semen was mixed with one part of extender III (base freezing extender III; TEY, 9.0\% glycerol). Group I was the control, with the addition of $1.5 \%$ Nova Equex STM paste. In the experimental groups, three different concentrations of Minitube Equex: Group II (1.5\%), Group III $(1.7 \%)$ and Group IV $(1.9 \%)$ were added to base freezing extender III and then to a final concentration of $1.0 \times 10^{9}$ sperm per $\mathrm{mL}$ and contained $3.0 \%$ glycerol (Buranaamnuay et al., 2009). Finally, the extended semen was loaded into 0.5 PVC-French straws (IMV Technologies, France) and sealed with PVC powder. In the freezing process, the straws were suspended horizontally $4 \mathrm{~cm}$ above liquid nitrogen $\left(-120^{\circ} \mathrm{C}\right)$ in a Styrofoam box for $20 \mathrm{~min}$ and plunged into liquid nitrogen $\left(-196^{\circ} \mathrm{C}\right)$. The cryopreserved semen was kept for one week before subsequent measurements.

\section{Sperm quality assessment}

For thawing, straws were dipped into a water bath at $50{ }^{\circ} \mathrm{C}$ for $12 \mathrm{sec}$. (Sellés et al., 2003). The thawed semen was resuspended into Duragen ${ }^{\circledR}$ extender. The post-thaw motility was determined after incubation at $37^{\circ} \mathrm{C}$ for 0 (10 min post-thawing), 1 and $2 \mathrm{~h}$ using a CASA system (SCA ${ }^{\circledR}$ CASA system, MICROPTIC S.L, Barcelona, Spain). The diluted semen was placed in a chamber and examined on a warmed stage (TOKAI HIT, Shizuoka-ken, Japan) at $37^{\circ} \mathrm{C}$ under a phase-contrast microscope (BX41, Olympus, Shinjuku, Japan) coupled to a video test sperm system (Wang et al, 
2018). A waiting period of $1 \mathrm{~min}$ was observed before each analysis (IguerOuada and Verstegen, 2001; Tretipskul et al., 2010). A minimum of five fields and 1000 spermatozoa were analysed for each sample. The user-defined parameter settings for the programme were as follows: frame rate (fps), 50; static $(\mu \mathrm{m} / \mathrm{s}),<10$; slow-medium $(\mu \mathrm{m} / \mathrm{s})$; 25; rapid $(\mu \mathrm{m} / \mathrm{s}),>45$; progressive (STR $>$ ), 45; connectivity (pixels), 11; velocity average path (VAP) points (pixels), 5. Average speed indices of sperm quality assessment, i.e., total motility, progressive motility, rapid velocity, velocity curved line $(\mathrm{VCL}, \mu \mathrm{m} / \mathrm{s})$, velocity straight line (VSL, $\mu \mathrm{m} / \mathrm{s})$, VAP $(\mu \mathrm{m} / \mathrm{s})$, linearity (LIN, as a measure of a curvilinear path, VSL/VCL, \%), straightness (STR, as the linearity of the average path, VSL/VAP, $\%$ ), wobble (WOB, oscillation measure of the actual path from the average path, $\mathrm{VAP} / \mathrm{VCL}, \%)$, amplitude of lateral sperm head $(\mathrm{ALH}, \mu \mathrm{m})$ and beat cross frequency $(\mathrm{BCF}, \mathrm{Hz})$, were determined using CASA.

\section{Statistical analysis}

Statistical analyses were performed using SAS (SAS version 9.0, Cary, NC, USA). All sperm motility characteristics were analysed by multiple ANOVA using the general linear mixed model procedure (MIXED) of SAS. The statistical models included a fixed effect of group (I, II, III, IV), time at 0 (10 min post-thawing), 1 and $2 \mathrm{~h}$, and the two-way interaction. Boar was included in the models as a random effect. Least-square means were obtained from the statistical models and compared using the least significant difference test. $P<0.05$ was regarded as statistically significant.

\section{Results}

The total and progressive motility results of frozen-thawed semen are shown in Figure 1a and 1b. Interestingly, the total motility in Group IV (53.2 \pm
$2.9 \%)$ was significantly higher than in Group II $(42.3 \pm 2.9 \%, P<0.001)$, and Group III $(44.7 \pm 2.9 \%, P=0.0007)$ after thawing at $0 \mathrm{~h}$ (10 min post-thawing). It also had a higher tendency than Group I (1.5\% Nova Equex STM paste (control); $46.3 \pm 3.5 \%, P=0.060$ ) though this difference was not significant. However, no effect of concentration on total motility was found at 1 and $2 \mathrm{~h}$ after thawing.

Progressive motility in Group IV $(40.02 \pm 2.71 \%)$ was higher than in Group II $(28.54 \pm 2.71 \%, P<0.001)$ and Group III $(32.0 \pm 2.7 \%, P=0.015)$ after thawing at $0 \mathrm{~h}$ and was higher than in Group I $(33.1 \pm 3.3 \%, P=0.057)$. However, no effect of concentration on progressive motility was found at 1 and $2 \mathrm{~h}$ after thawing.

The significant levels of the individual kinetic indicators are shown in Table 1. Regarding time after thawing at 0, 1 and 2 $h$, all groups were statistically significant different $(P<0.001)$.

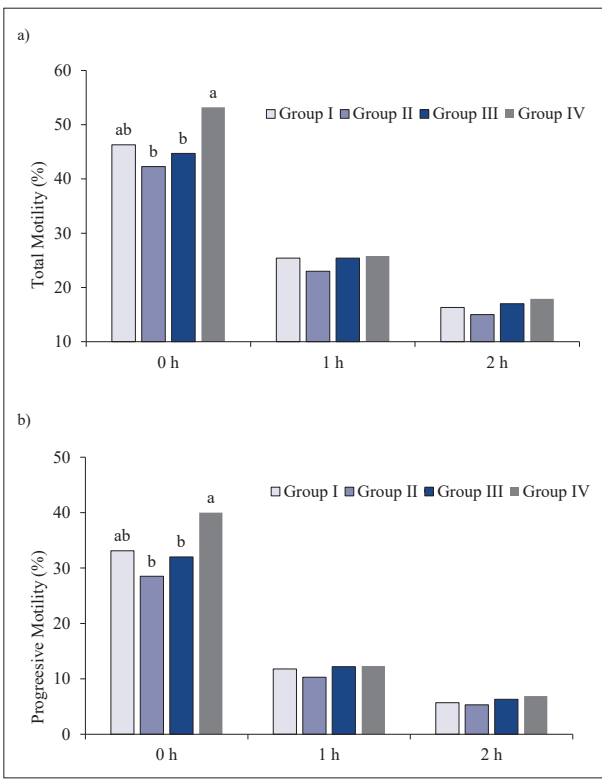

Figure 1. Total motility (a) and progressive motility (b) in each group at 0 h $(10 \mathrm{~min}$ postthawingl, $1 \mathrm{~h}$ and $2 \mathrm{~h}$. ${ }^{\mathrm{a}, \mathrm{b}}$ significant difference within group $(P<0.05)$ 
The individual kinetic indicators are demonstrated in Table 2. In Group IV after thawing at $0 \mathrm{~h}(10 \mathrm{~min}$ postthawing), rapid velocity and VCL were significantly higher than in Groups II and III, though the difference from Group I was not statistically significant. Likewise, VSL, VAP, LIN, STR, ALH, BCF in Group IV were significantly different from Group II $(P<0.05)$, but not between Groups I and III. The WOB kinetic indicator of Group IV was highest among all groups $(P<0.05)$.

After thawing at $1 \mathrm{~h}$, LIN in Group IV showed a higher value than in Group II, but was not different from the others. Moreover, STR values in both Groups III and IV were higher than in Group I $(P<0.05)$, but did not differ significantly from Group II. All sperm kinematics at 2 $\mathrm{h}$ after thawing did not differ significantly among groups $(P>0.05)$.

\section{Discussion}

Cryopreserved spermatozoa are characterised by a decline in motility. The majority of samples showed a variable degree of impairment, while the minority exhibited vigorous forward progressive motility. This would seem to be an important contribution to their relatively poor fertilising potential when introduced into the reproductive tract during artificial insemination (Watson, 2000). Consistently in this study, the motility characteristics of frozen-thawed spermatozoa decreased gradually over the incubation times of 0,1 and $2 \mathrm{~h}$. Nevertheless, the total motility and progressive motility in Group IV $(1.9 \%$ Minitube Equex paste) was higher than in Group II (1.5\%) and Group III (1.7\%) after thawing at $0 \mathrm{~h}$ and higher than in Group I (1.5\% Nova Equex STM paste; control). Likewise, the WOB kinetic indicator of Group IV was the highest among all groups.

After thawing at $1 \mathrm{~h}$, the linearity (LIN) in Group IV showed a higher value than in Group II, but this did not differ significantly from the other groups. It appeared that the concentration of Minitube Equex paste at $1.9 \%$ gave a better result than Group II $(1.5 \%)$, but was not significantly different at $1.7 \%$ or from the control (1.5\% Nova Equex STM paste). Several studies have previously

Table 1. Significant levels of the individual kinetic indicators between group and time

\begin{tabular}{|c|c|c|c|}
\hline Sperm kinematic & Group & Time & Group $\times$ Time \\
\hline Total motility & 0.026 & $<0.001$ & 0.445 \\
\hline Progressive motility & 0.051 & $<0.001$ & 0.300 \\
\hline Rapid velocity & 0.205 & $<0.001$ & 0.485 \\
\hline VCL & 0.279 & $<0.001$ & 0.725 \\
\hline VSL & 0.116 & $<0.001$ & 0.925 \\
\hline VAP & 0.091 & $<0.001$ & 0.872 \\
\hline LIN & 0.014 & $<0.001$ & 0.892 \\
\hline STR & 0.011 & $<0.001$ & 0.596 \\
\hline WOB & 0.005 & $<0.001$ & 0.873 \\
\hline ALH & 0.321 & $<0.001$ & 0.799 \\
\hline BCF & 0.012 & $<0.001$ & 0.517 \\
\hline
\end{tabular}




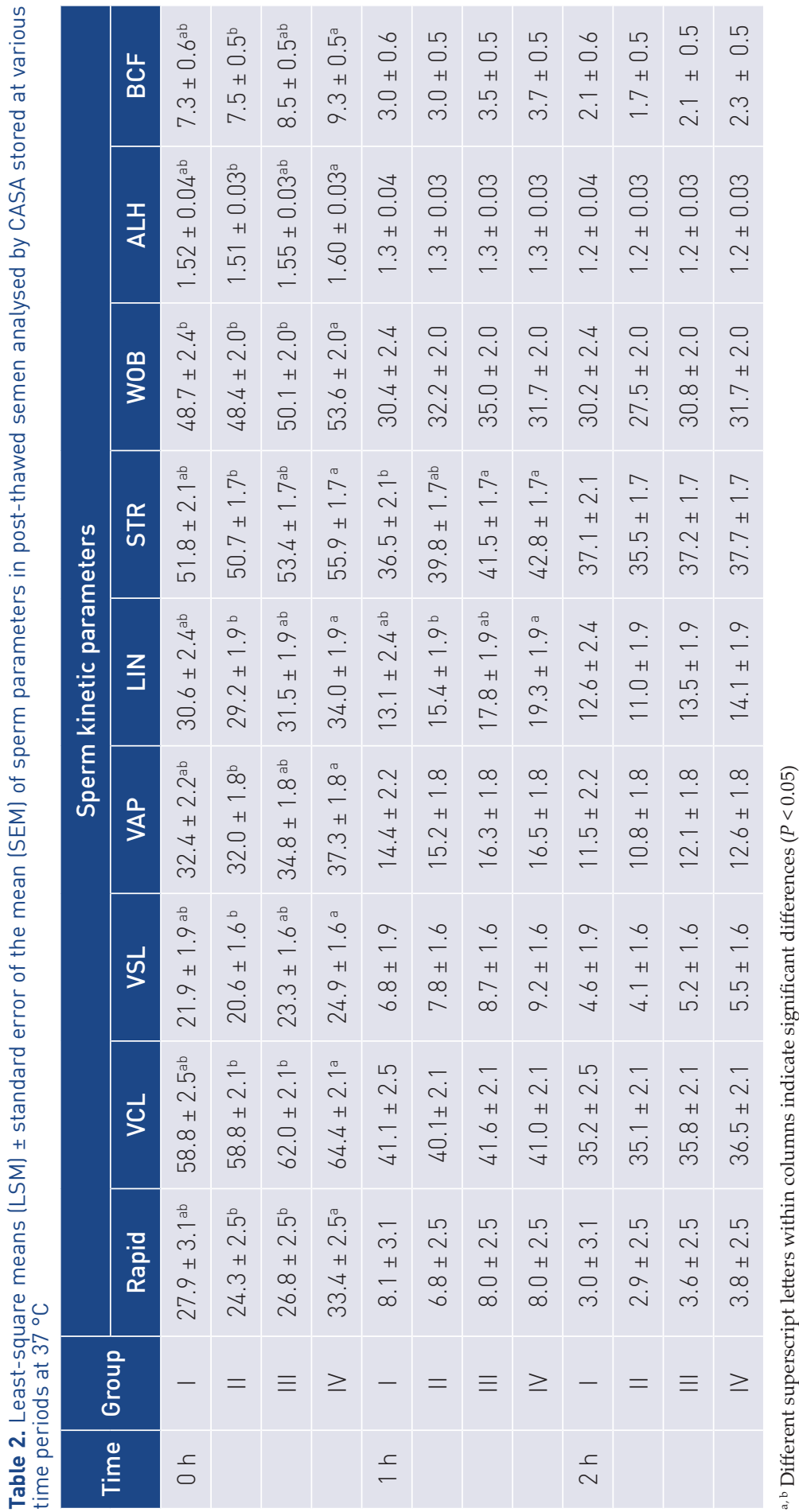


reported significant beneficial effects of the linearity (LIN) indicator in swine reproduction field trials. Boar semen containing spermatozoa exhibiting increased VSL and LIN is associated with larger litter sizes after insemination (Holt et al., 1997; Estienne et al., 2007). Furthermore, farrowing rate is related to VCL, LIN and hyperactivated sperm (Oh et al., 2010). Sutkeviciene et al. (2005) also demonstrated that only these three sperm parameters are correlated with the non-return rate when studying the relationship between sperm kinetics and in vivo fertility.

In terms of artificial insemination, the linearity (LIN) of sperm movement on the day of collection and the wobble (WOB) after storage influenced the total number of piglets born (TNB) in Norwegian Landrace, while the percentage of motile cells, curvilinear velocity (VCL) and lateral head amplitude (ALH) on the day of semen collection and LIN after storage influenced TNB in Norwegian Duroc (Tremoen et al., 2018). Concurrently, the variables VCL, ALH, LIN and WOB affected TNB when using one or more assessment models, and all these variables among the threshold values (receiver operating characteristic (ROC) curve analysis) defining the swimming pattern of hyperactive sperm (Schmidt and Kamp, 2004).

After thawing at $1 \mathrm{~h}$, STR values in both Groups III and IV were significantly higher than in Group I, but not significantly different in Group II, which indicated that the concentrations of Minitube Equex paste at 1.5\%, 1.7\% and $1.9 \%$ gave better results than the control (1.5\% Nova Equex STM paste). As previously mentioned, the benefit of the straightness (STR) value was indicated in production settings with respect to sperm motion. Amann and Waberski, (2014) recommended that VCL and STR should be considered for each spermatozoon, with categorisation into three groups: (1)
Immotile, VCL near zero; (2) Undesirable, low VCL; and (3) Satisfactory, VCL and STR meeting standards. Only semen having a sufficient percentage of 'Satisfactory' sperm compared to the standard can be processed and shipped. Nonetheless, sperm motility assays can be used for mammalian sperm: a normal distribution in the CASA results was apparent and their capacity to predict fertilising ability in boars needs to be evaluated (Vizcarra and Ford, 2006).

Prior to freezing, a holding time at cooling temperature before further processing for cold-storage $\left(4{ }^{\circ} \mathrm{C}\right)$ must be observed, because it has been reported that the incubation time of sperm in seminal plasma before freezing has a beneficial effect in improving the resistance of sperm to cold shock, or can result in a reversal of the sperm capacitation process (Vadnais et al., 2005; Juarez et al., 2011; Tomás et al., 2014). Moreover, the holding time in semen processing can protect boar spermatozoa against cold injury through maintenance of the lipid architecture of the plasma membrane (Casas and Althouse, 2013). Purdy et al. (2010) also demonstrated that temperature can affect the sperm quality of boar semen during cryopreservation. The optimal pre-freeze holding temperature is approximately $16{ }^{\circ} \mathrm{C}$; this was used in this study, since it gave a beneficial effect on postthawed spermatozoa with the highest total motility, progressive motility and velocities (VCL, VSL and VAP), as well as the types of motion (LIN, ALH and BCF).

The most-used permeating CPA for sperm of various species is glycerol. Glycerol exerts an extracellular effect by osmotic stimulation of cell dehydration, thus decreasing the volume of intracellular water available for freezing. This effect depends on the concentration used, but glycerol is toxic and can induce membrane damage and decrease sperm motility (Medeiros et al., 2002). Most 
research adding cryoprotectant in boar freezing used LEY (lactose-egg yolk extender) base extender III supplemented with $9.0 \%$ glycerol plus $1.5 \%$ Nova Equex STM paste (Sancho et al., 2007; Buranaamnuay et al., 2009; Mercado et al., 2009; Tretipskul et al., 2010; Chanapiwat et al., 2012; Pearodwong et al., 2019). Nevertheless, some studies used LEY (lactose-egg yolk extender) base extender III, supplemented with $6.0 \%$ glycerol plus $1.5 \%$ Nova Equex STM paste (Roca et al., 2006; Tomás et al., 2014; Resende et al., 2019). However, in this study, we used TEY (Tris-egg yolk extender) base extender III (De Mercado et al., 2009), supplemented with 9.0\% glycerol, plus different concentrations of Minitube Equex paste compared with Nova Equex STM paste (as the control), because it gave better results of motility of post-thawed spermatozoa than LEY (lactose-egg yolk extender) base extender III supplemented with $6 \%$ glycerol plus $1.5 \%$ Nova Equex STM paste (data not shown).

The main active mechanism of Equex paste is to improve the post-thawing survival of spermatozoa by acting as a surfactant to stabilise the cell membrane, particularly the acrosome membrane, and to protect spermatozoa against the toxic effects of glycerol during the freeze-thaw process (Arriola and Foote, 1987). Despite the prolonged incubation of sperm in freezing extender supplemented with Equex paste having an adverse effect on sperm membrane/viability, probably by the toxic effect of Equex paste (Axnér et al., 2004), the addition of Equex paste should be put into extender III prior to the freezing process.

Currently, Equex paste produced by Nova Chemical is not available, and instead it could be replaced by Equex paste from Minitube. Some reports have used slightly different concentrations of freezing extender for boar semen cryopreservation. Sellés et al. (2003) used LEY (Lactose-egg yolk extender) base extender III supplemented with 9\% glycerol plus 1.5\% Minitube Equex paste. In contrast, Purdy et al. (2010) used TEY-based freezing extender III supplemented with $6 \%$ glycerol plus 2.5\% Minitube Equex paste. Based on the present study, the use of Minitube Equex paste at $1.9 \%$ greatly improved total motility, progressive motility and all sperm kinetic parameters compared to other concentrations $(1.5 \%$ and $1.7 \%)$, but similar to Nova Equex STM paste supplemented with $9 \%$ glycerol in TEY-based freezing extender III. Hence, Minitube Equex paste could be a suitable replacement for Nova Equex STM paste. Nonetheless, the optimal proportion of glycerol and Minitube Equex paste is still unclear, and requires further study.

In conclusion, the most suitable concentration of Minitube Equex paste in the current protocol was $1.9 \%$, supplemented with $9.0 \%$ glycerol in Triscitrate egg yolk-based freezing extender III. This showed conformity between data from manual guides and the observed results on sperm motility characteristics. This indicates that the final concentration of Minitube Equex paste on cryopreserved boar semen should be $0.63 \%$, which is in agreement with the recommended dose from the manufacture's guide of 0.60 $0.80 \%$.

\section{Acknowledgments}

Financial support for the present study was provided by a Thailand Science Research and Innovation Senior Researcher Scholar (RTA6280013) and the Faculty of Veterinary Science Research Fund, Chulalongkorn University, 2020 (RG 12/2563).

\section{References}

1. ALHAIDER, A. K. and P. F. WATSON (2009): Cryopreservation of dog semen: The effects of Equex STM paste on plasma membrane fluidity and the control of intracellular free calcium. Anim. Reprod. Sci. 110, 147-161. 
Determination of the optimal concentration of Minitube Equex paste for boar semen cryopreservation based on sperm motility characteristics

Određivanje optimalne koncentracije Minitube Equex paste za krioprezervaciju sjemena nerasta prema karakteristikama pokretljivosti sperme

2. AMANN, R. P. and D. WABERSKI (2014): Computer-assisted sperm analysis (CASA) capabilities and potential developments. Theriogenology. 81, e11-e13.

3. ANNAKKUL, N., J. SUWIMONTEERABUTR, J. SINGLOR, N. PHUTIKANIT, T. THARASANIT and M. TECHAKUMPHU (2011): Effect of Equex STM Paste on the quality and Motility characteristics of post thawed cryopreserved goat semen. Thai. J. Vet. Med. 41, 345-351.

4. ARRIOLA, J. and R. H. FOOTE (1987): Glycerolation and thawing effects on bull spermatozoa frozen in detergent-treated egg yolk and whole egg extenders. J. Dairy Sci. 70, 1664-1670.

5. AXNÉR, E., U. HERMANSSON and C. LINDEFORSBERG (2004): The effect of Equex STM paste and sperm morphology on post-thaw survival of cat epididymal spermatozoa. Anim. Reprod. Sci. 84, 179-191.

6. BENSON, J. D., E. J. WOODS, E. M. WALTER and J. K. CRITSER (2012): The cryobiology of spermatozoa. Theriogenology 78, 1682-1699.

7. BURANAAMNUAY, K., P. TUMMARUK, J. SINGLOR, H. RODRIGUEZ-MARTINEZ and M. TECHAKUMPHU (2009): Effects of straw volume and Equex STM (R) on boar sperm quality after cryopreservation. Reprod. Domest. Anim. 44, 69-73.

8. BURANAAMNUAY, K., S. MAHASAWANGKUL and K. SAIKHUN (2013): The in vitro quality of frozen-thawed Asian elephant (Elephas maximus) spermatozoa in semen supplemented with Equex STM paste and oxytocin during and after cryopreservation. Reprod. Biol. 13, 169-171.

9. CASAS, I. and G. C. ALTHOUSE (2013): The protective effect of a $17{ }^{\circ} \mathrm{C}$ holding time on boar sperm plasma membrane fluidity after exposure to $5{ }^{\circ} \mathrm{C}$. Cryobiology 66, 69-75.

10. CHANAPIWAT, P., K. KAEOKET and P. TUMMARUK (2012): Cryopreservation of boar semen by egg yolk-based extenders containing lactose or fructose better than sorbitol. J. Vet. Med. Sci. 74, 351-354.

11. De MERCADO, E., M. HERMANDEZ, E. SANZ, A. RODRINGUEZ, E. GOMEZ, J. M. VAZQUEZ, E. A. MARTINEZ and J. ROCA (2009): Evaluation of L-glutamine for cryopreservation of boar spermatozoa. Anim. Reprod. Sci. 115, 149-157.

12. ESTIENNE, M. J., A. F. HARPER and J. L. DAY (2007): Characteristics of sperm motility in boar semen diluted in different extenders and stored for seven days at $18{ }^{\circ} \mathrm{C}$. Reprod. Biol. 7, 221-231.

13. GAO, G. Y., E. ASHWORTH, P. F. WATSON, F. W. KLEINHANS, P. MAZUR and J. K. CRITSER (1993): Hyperosmotic tolerance of human spermatozoa: separates effects of glycerol, sodium chloride and sucrose on spermolysis. Biol. Reprod. 49, 112-123.

14. HOLT, C., W. V. HOLT, H. D. M. MOORE, H. C. B. REED and R. M. CURNOCK (1997): Objectively measured boar sperm motility parameters correlate with the outcomes of on-farm inseminations: results of two fertility trials. J. Androl. 18, 312-323.

15. HOLT, W. V. (2000): Basic aspects of frozen storage of semen. Anim. Reprod. Sci. 62, 3-22.

16. IGUER-OUADA, M. and J. P. VERSTEGEN (2001): Evaluation of the Hamilton throne computerbased automated system for dog semen analysis. Theriogenology 55, 733-749.

17. JOHNSON, L. A., K. F. WEITZE, P. FISER and W. M. C. MAXWELL (2000): Storage of boar semen. Anim. Reprod. Sci. 62, 3-22.

18. JUAREZ, J. D., I. PARRILLA, J. M. VAZQUEZ, E. A. MARTINEZ and J. ROCA (2011): Boar semen can tolerate rapid cooling rates prior to freezing. Reprod. Ferti. Develop. 23, 681-690.

19. KARAGEORGIOU, M. A., G. TSOUSIS, C. M. BOSCOS, E. D. TZIKA, P. D. TASSIS and I. A. TSAKMAKIDIS (2016): A comparative study of boar semen extenders with different proposed preservation times and their effect on semen quality and fertility. Acta. Vet. Brno. 85, 23-31.

20. KOZDROWSKI, R., A. DUBIEL, W. BIELAS and M. DZIECIOL (2007): Two protocols of cryopreservation of goat semen with the use of computer-assisted semen analysis system. Acta. Vet. Brno. 76, 604-604.

21. MEDEIROS, C. M. O., F. FORELL, A. T. D. OLIVERIRA and J. L. RODRIGUES (2002): Current status of sperm cryopreservation: why isn't it better? Theriogenology 57, 327-344.

22. MORTON, K. M., G. EVANS and W. M. C. MAXWELL (2010): Effect of glycerol concentration, Equex STM ${ }^{\circledast}$ supplementation and liquid storage prior to freezing on the motility and acrosome integrity of frozen-thawed epididymal alpaca (Vicugna pacos) sperm. Theriogenology 74, 311316.

23. OKAZAKI, T., S. ABE and M. SHIMADA (2009): Improved conception rates in sows inseminated with cryopreserved boar spermatozoa prepared with a more optimal combination of osmolarity and glycerol in the freezing extender. Anim. Reprod. Sci. 80, 121-129.

24. OH, S. A., Y. J. PARK, Y. A. YOU, E. A. MOHAMED and M. G. PANG (2010): Capacitation status of stored boar spermatozoa is related to litter size of sows. Anim. Reprod. Sci. 121, 131-138.

25. PANYABORIBAN, S., J. SUWIMONTEERABUTR, N. PHUTIKANIT, T. SWANGCHAN-UTHAI, T. THARASANIT and M. TECHAKUMPHU (2015): Effect of various combinations of sugar supplementation in the extender on frozen-thawed ram semen quality and fertility. Thai. J. Vet. Med. 45, 229-237.

26. PONGLOWHAPAN, S. and K. CHATDARONG (2008): Effects of Equex STM Paste on the quality of frozen-thawed epididymal dog spermatozoa. Theriogenology 69, 666-672.

27. PEARODWONG, P., J. SUWIMONTEERABUTR, J. RUNGRUANGSAK and P. TUMMARUK (2019): Comparison of egg yolk-based and soybean 
lecithin-based extenders for cryopreservation of boar semen. Vet. stn. 50, 531-540.

28. PURDY, P. H. (2008): Ubiquitination and its influence in boar sperm physiology and cryopreservation. Theriogenology 70, 818-826.

29. PURDY, P. H., N. THARP, T. STEWART, S. F. SPILLER and H. D. BLACKBURN (2010): Implication of the $\mathrm{pH}$ and temperature of diluted, cooled boar semen on fresh and frozen-thawed sperm motility characteristics. Theriogenology 74 , 1304-1310.

30. RESENDE, C. O., R. P. BETARELLI, S. S. RABELO, B. R. CHAVES, J. E. RODRIGUEZ-GIL and M. G. ZANGERONI (2019): Addition of Insulin-like growth factor I (IGF-I) and reduced glutathione (GSH) to cryopreserved boar semen. Anim. Reprod. Sci. 208: September 2019, 10613.

31. ROCA, J., M. HERNÁNDEZ, J. CARVAJAL, J. M. VÁZQUEZ and E. A. MANTÍNEZ (2006): Factors influencing boar sperm cryosurvival. J. Anim. Sci. 84, 2692-2699.

32. RODRIGUEZ-MARTINEZ, H. and M. WALLGREN (2010): Advances in boar semen cryopreservation. Vet. Med. Intern. 2011. http:// dx.doi.org/10.4061/2011/396181

33. SANCHO, S., I. CASAS, H. EKWALL, F. SARAVIA, H. RODRIGUEZ-MARTINEZ, J.E. RODRIGUEZGIL, E. FLORES, E. PINART, M. BRIZ, N. GARCIAGIL, J. BASSOLS, A. PRUNEDA, E. BUSSALLEU, M. TESTE and S. BONET (2007): Effects of cryopreservation on semen quality and the express of sperm membrane hexose transporters in the spermatozoa of Iberian pigs. Reproduction 134, 111-121.

34. SELLÉS, E., J. GADEA, R. ROMAR, C. MATAS and S. RUIZ (2003): Analysis of in vitro fertilizing capacity to evaluate the freezing procedures of boar semen and to predict the subsequent fertility. Reprod. Domest. Anim. 38, 66-72.

35. SCHMIDT, H. and G. KAMP (2004): Induced hyperactivity in boar spermatozoa and its evaluation by computer-assisted sperm analysis. Reproduction 128, 171-179.

36. SUTKEVICIENE, N., M. A. ANDERSSON, H. ZILINSKAS and M. ANDERSSON (2005): Assessment of boar semen quality in relation to fertility with special reference to methanol stress. Theriogenology 63, 730-747.

37. TOMÁS, C., J. GÓMEZ-FERNÁNDEZ, E. GÓMEZ-IZQUIERDO and E. De MARCADO (2014): Effect of the holding time at $15^{\circ} \mathrm{C}$ prior to cryopreservation, the thawing rate and the post- thaw incubation temperature on the boar sperm quality after cryopreservation. Anim. Reprod. Sci. 144, 115-121.

38. TREMOEN, N.H., A. H. GAUSTAD, I. ANDERSONRANBERG, M. VAN SON, T. T. ZEREMICHAEL, K. FRYDENLUND, E. GRINFLEK, D. I. VÅGE and F. D. MYROMSLIEN (2018): Relationship between sperm motility characteristics, and association with fertility in two different pig breeds. Anim. Reprod. Sci. 193, 226-234.

39. TRETIPSKUL, C., K. BURANAAMUAY, S. KOONJAENAK, P. TUMMARUK and $M$. TECHAKUMPHU (2010): The use of computerassisted sperm analysis for discriminating series of motility pattern of frozen-thawed boar semen. Thai. J. Vet. Med. 40, 25-30.

40. VADNAIS, M. L., R. KIRKWOOD, D. SPRECHER and K. CHOU (2005): Effects of extender incubation temperature and added seminal plasma on capacitation of cryopreserved, thawed boar sperm as determined by chlorotetracycline staining. Anim. Reprod. Sci. 90, 347-354.

41. VAN DEN BERGHE, F., M. C. J. PARIS, M. B. BRIGGS, W. K. FARSTAD and D. B. B. P. PARIS (2018): A two-step dilution tris-egg yolk extender containing Equex STM significantly improves sperm cryopreservation in the African wild dog (Lycaon pictus). Cryobiology 80, 18-25.

42. VIZCARRA, J. A. and J. J. FORD (2006): Validation of the sperm motility assay in boars and stallions. Theriogenology 66, 1091-1097.

43. VYT, P., D. MAES, T. RIJSSELAERE, E. DEJONCKHEERE, F. CASTRYCK and A. VAN SOOM (2004): Motility Assessment of porcine spermatozoa: a comparison of methods. Reprod. Domest. Anim. 39, 447-453.

44. WANG, S., M. SUN, N. WANG, K. YANG, H. GUO, J. WANG, Y. ZHANG, S. YUE and J. ZHOU (2018): Effects of L-glutamine on boar sperm quality during liquid storage at $17^{\circ} \mathrm{C}$. Anim. Reprod. Sci. 191, 76-84.

45. WATSON, P. F. (2000): The causes of reduced fertility with cryopreserved semen. Anim. Reprod. Sci. 60-61, 481-492.

46. WORLD HEALTH ORGANIZATION (2010): Laboratory Manual for the Examination and Processing of Human semen. $5^{\text {th }}$ edn. World Health Organization. Geneva (136-141).

47. YESTE, M. (2016): Sperm cryopreservation update: Cryodamage, markers, and factors affecting the sperm freezability in pigs. Theriogenology 85, $47-64$. 


\section{Određivanje optimalne koncentracije Minitube Equex paste za krioprezervaciju sjemena nerasta prema karakteristikama pokretljivosti sperme}

Junpen SUWIMONTEERABUTR, Morakot NUNTAPAITOON, dr. sc. Padet TUMMARUK, dr. med. vet., Faculty of Veterinary Science, Univerzitet Chulalongkorn, Bangkok, Tajland

Equex pasta je neprožimajuće kriozaštitno sredstvo (CPA) za koje je dobro poznato da poboljšava preživljavanje spermija nakon odmrzavanja tijekom krioprezervacije sjemena nerasta. Međutim, Equex pasta koju proizvodi tvrtka Nova Chemical Sales Inc. (MA, SAD) trenutno nije dostupna na tržištu. Cilj ove studije bio je odrediti optimalnu koncentraciju Minitube Equex paste (Minitube, Tiefenbach, Njemačka) za krioprezervaciju sjemena nerasta u usporedbi s Nova Equex STM pastom (kontrola). Prikupljeno je petnaest ejakulata 12 zrelih nerasta metodom manualne fiksacije penisa. Svaki ejakulat bio je raspodijeljen i krioprezerviran $\mathrm{u}$ osnovnom razrjeđivaču za duboko zamrzavanje III - razrjeđivač trinatrijev citrat $\mathrm{s}$ dodatkom žutanjka jajeta (TEY) plus 9,0\% glicerola, razvrstano u četiri skupine (tj. skupine I, II, III i IV). Skupina I: 1,5 \% Nova Equex STM pasta (kontrola) i tri različite koncentracije Minitube Equex paste (Skupina II: 1,5 \%; Skupina III: 1,7 \%; i Skupina
IV: 1,9\%) dodano je osnovnom razrjeđivaču za duboko zamrzavanje III. Nakon zamrzavanja i odmrzavanja, karakteristike pokretljivosti spermija procijenjene su pomoću analizatora sperme Sperm Class Analyzer ${ }^{\circledast}$ inkubirano na $37^{\circ} \mathrm{C}, 0$ (10 $\left.\mathrm{min}\right), 1$ i $2 \mathrm{~h}$ nakon odmrzavanja. U Skupini IV, $0 \mathrm{~h}$ nakon odmrzavanja, brzina i krivulja brzine bile su značajno više nego u Skupinama II i III $(P<0,05)$, ali se nisu razlikovale od Skupine I. Nadalje, $1 \mathrm{~h}$ nakon odmrzavanja, LIN (linearnost) u Skupini IV bila je veća nego u Skupini II $(P<0,05)$, ali se nije razlikovala od ostalih skupina. Zaključno, najprikladnija koncentracija Minitube Equex paste u ovom protokolu bila je 1,9\% uz dodatak 9,0 \% glicerola u TEY razrjeđivaču za zamrzavanje III, zbog sukladnosti između podataka iz priručnika i zamijećenih rezultata karakteristika pokretljivosti spermija.

Ključne riječi:sjemenerasta, krioprezervacija, razrjeđivač, Equex pasta, pokretljivost nakon odmrzavanja 